$5-1-2011$

\title{
Franchise Partnership And International Expansion: A Conceptual Framework And Research Propositions
}

\author{
Dhruv Grewal \\ Babson College, dgrewal@babson.edu \\ Golpalkrishnan R. lyer \\ Florida Atlantic University, GIYER@FAU.EDU \\ Rajshekar G. Javalgi \\ Cleveland State University, r.javalgi@csuohio.edu \\ Lori Radulovich

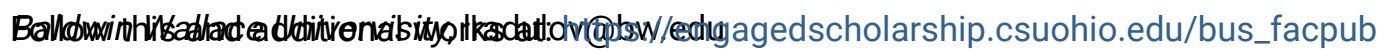 \\ Part of the Entrepreneurial and Small Business Operations Commons, and the International Business

\section{Commons}

How does access to this work benefit you? Let us know!

\section{Publisher's Statement}

This is the accepted version of the following article: Grewal, D., lyer, G.R., Javalgi, R.G., \&

Radulovich, L. Franchise partnership and international expansion: A conceptual framework and research propositions. Entrepreneurship Theory and Practice, 35(3), 533-557. doi:10.1111/

j.1540-6520.2011.00444.x, which has been published in final form at

http://onlinelibrary.wiley.com/doi/10.1111/j.1540-6520.2011.00444.x/abstract

\section{Original Published Citation}

Grewal, D., lyer, G.R., Javalgi, R.G., \& Radulovich, L. Franchise partnership and international expansion: A conceptual framework and research propositions. Entrepreneurship Theory and Practice, 35(3), 533-557. doi:10.1111/j.1540-6520.2011.00444.x

This Article is brought to you for free and open access by the Monte Ahuja College of Business at EngagedScholarship@CSU. It has been accepted for inclusion in Business Faculty Publications by an authorized administrator of EngagedScholarship@CSU. For more information, please contact library.es@csuohio.edu. 


\title{
Franchise Partnership \\ and International \\ Expansion: A \\ Conceptual Framework \\ and Research \\ Propositions
}

\author{
Dhruv Grewal
}

Gopalkrishnan R. Iyer

Rajshekhar (Raj) G. Javalgi

Lori Radulovich

\begin{abstract}
Although academic research has provided tremendous insights about the organizational form of franchising, considerable work remains with regard to understanding the critical factors that enable international franchise expansion and performance. The authors advance the argument that a franchise relationship is essentially an entrepreneurial partnership, and that this partnership influences the speed, scale, and scope of franchise expansion into international markets. In the proposed conceptual model, the authors detail the links among the franchise partnership, international expansion, and franchise system performance.
\end{abstract}

$\mathbf{I}_{\mathrm{n}}$ the past four decades, franchising has grown tremendously as an organizational form, especially in retail and food service sectors. Academic research on franchising has kept pace, producing vast streams of pertinent literature within economics, law, management, finance, marketing, and entrepreneurship that pertains to the organization, growth, expansion, and performance of franchise systems. For example, prior research has examined franchise systems as reasonable economic alternatives to other organizational forms (Dant \& Kaufmann, 2003; Rubin, 1978), identified reasons for franchisor ownership of outlets (Brickley \& Dark, 1987; Caves \& Murphy, 1976; Combs \& Castrogiovanni, 1994; Oxenfeldt \& Kelly, 1968), listed reasons entrepreneurs may seek franchising as an alternative to starting their own business (Kaufmann, 1999; Peterson \& Dant, 1990), and considered how incentives and controls can align the disparate objectives of franchisors and franchisees (Brickley \& Dark; Lafontaine, 1992; Rubin). Research also has attempted to uncover factors that may contribute to the success or failure of franchise systems (Dant,

Please send correspondence to: Dhruv Grewal, tel:: (781) 239-3902; e-mail: dgrewal@babson.edu, to Gopalkrishnan R. Iyer at giyer@fau.edu, to Rajshekhar (Raj) G. Javalgi at R.Javalgi@ csuohio.edu, and to Lori Radulovich at lradulov@bw.edu. 
Kacker, Coughlan, \& Emerson, 2007; Kaufmann \& Dant, 1996; Michael \& Combs, 2008; Shane, 1998, 2001; Shane \& Spell, 1998).

The success of franchising as an organizational form has spawned multiple perspectives on why, and in which contexts, franchising provides a superior organizational alternative and how franchise firms expand through a combination of franchised and company-owned outlets. Such a predominant focus on the franchise contract and franchise ownership has overshadowed other important questions, including why many franchises fail soon after inception, even as others expand successfully, not only in domestic markets but also internationally (Shane \& Spell, 1998). In franchising, performance depends on the joint actions of two distinct firms, the franchisor and franchisee, legally bound by the franchise contract. A search for factors that contribute to superior performance warrants an inquiry into the nature of the partnership between the franchisor and the franchisee, as well as various other factors that could affect success. Therefore, we focus on the partnership characteristics of the franchisor-franchisee relationship to uncover specific issues that could influence franchise expansion into international markets and eventually affect performance.

Building on Anderson and Narus's (1990) conceptualization of interfirm relationships in marketing, we acknowledge that each party in the franchise relationship recognizes the other's importance and engages in joint strategic actions to identify and take advantage of new market entry opportunities. In international expansion, franchisors often engage in contractual relations with established local companies, designated as master franchisees, to exploit an international market opportunity. Thus, their partnership is akin to an interfirm partnership rather than a contract between a franchisor at the firm level and an individual, entrepreneurial franchisee. Franchisors risk their resources to expand and develop the franchise concept and its operating system and undertake further risk when they transfer these resources to franchisees. A franchisor also risks the resources it invests in the brand and potential losses of brand equity. The franchisee firm risks resources that it invests to acquire tangible assets and intangible rights that are specific to the franchise. Both parties are motivated by new market opportunities and engage in innovative behaviors that enable them to exploit those opportunities. Accordingly, franchisor and franchisee firms form a distinct entrepreneurial partnership.

With the conceptual model we elaborate hereafter, we contend that the entrepreneurial orientations (EOs) and perceived dependence of the franchise partners shape the EOs and interdependence of the franchise partnership and thus affect franchise expansion in international markets and eventual performance. In the next section, we comment briefly on the paucity of theories that explain the franchise partnership before elaborating on how the franchise partnership in international expansion is shaped by the EOs of the partners and their perceived dependence on each other. We identify the impacts of the partnership on franchise expansion and then consider several moderating influences in the links among franchise partnership, expansion, and performance as charted in Figure 1 (for the definitions and potential operationalization of the key constructs, see Table 1). In conclusion, we draw some implications from our conceptual framework and offer suggestions for further research.

\section{Franchise Partnership, Franchise Expansion, and Performance}

Existing theoretical frameworks on franchising, which focus on the central problem of assuring coordination, are less effective for explaining entrepreneurial partnerships between the franchisor and the franchisee in the creation of a new franchise venture. 
Figure 1

International Franchise Expansion Framework

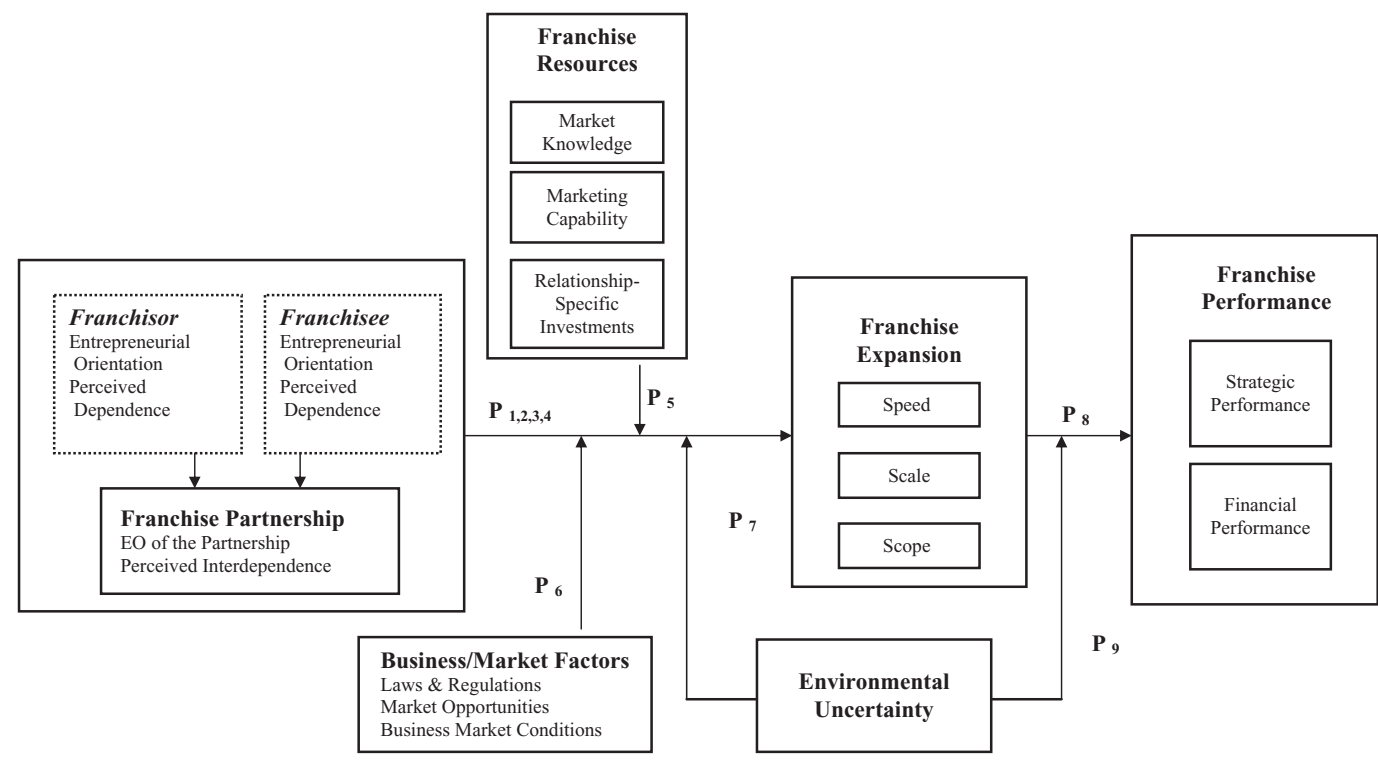

Prominent theories that are relevant to understanding franchising, as identified by Baker and Dant (2008) and Dant and Kaufmann (2003), include resource constraints, agency, transaction costs economics, signaling, and resource-based views. We provide a summary of these theories and their implications for the entrepreneurial nature of the franchise partnership in Table 2 .

These theories suggest that franchising creates incentives for coordination (Michael, 2002) and potential for conflicts (Leblebici \& Shalley, 1996). Some implications for franchise partnerships can be gleaned from each theoretical perspective, but these perspectives are limited in two important ways: (1) their focus is primarily on explaining the viability of franchising as an organizational form, and (2) they are more concerned with organizational arrangements in franchising. Thus, elaboration of the franchise relationship and the factors affecting franchise expansion and performance are not directly obtained from these perspectives. We echo Combs and Ketchen's (2003) suggestion that theoretical explanations in franchising need to move beyond these dominant perspectives and contend that a focus on the entrepreneurship involved in franchise expansion is fertile ground for understanding its structure and dynamics.

Our conceptualization of the franchise partnership thus follows from the nexus of franchising and entrepreneurship. Kaufmann and Dant (1998, p. 11) note that franchising is an "entrepreneurial partnership" that suggests "a much more complex entrepreneurial role for both franchisor and franchisee." Shane and Hoy (1996, p. 326) similarly assert that "franchising is an organizational form which requires one set of entrepreneurs to cooperate with another set of entrepreneurs who purchase the former's organizational routines." Thus, franchising is more than an entrepreneurial business venture, because the business concept and the contractual relationship require an entrepreneurial partnership.

Viewing a franchise partnership as an entrepreneurial partnership enables the explicit recognition of the orientations and objectives of both the franchisor and the franchisee. 


\section{Concept Definitions and Suggestions for Operationalization}

EO of the franchisor/franchisee: The processes, practices, and decision-making activities that lead to new entry. It is composed of three dimensions: innovativeness, proactiveness, and risk-taking.

Perceived dependence of the franchisor/franchisee: The extent to which the party relies on important resources provided by the other party in the absence of other alternatives.

EO of the franchise partnership: The extent to which the franchise partners jointly engage in making strategies and implementing entrepreneurial decisions and actions.

Interdependence of the franchise partnership: The extent to which both parties to the franchise relationship are dependent on each other.

Local market knowledge: Knowledge of local market customers and competitors available to the franchise partnership.

Marketing capability: The extent to which the partnership is able to pool and use marketing assets to formulate and implement competitively superior marketing strategy.

RSI: Investments made by either or both parties that do not have value outside of the partnership.

Business/market factors: The extent to which the business environment is favorable to franchising and to the franchise partnership.

Environmental uncertainty: The extent to which the environment reflects turbulence and dynamism.

Franchise expansion: The extent to which the franchise has grown in terms of the speed of expansion, scale of operations, and geographical scope of expansion.

Franchise performance: Strategic performance in terms of development of market-based assets that can be harvested for future performance and current financial performance of the franchise.
Meta-analysis by Rauch et al. (2009) reveals that the original scale offered by Covin and Slevin (1989) can be refined or modified without loss of validity. The EO dimensions are additive, and a summed index can be used. A second-order latent EO construct is recommended to examine the effects of EO dimensions on the partnership, partner perceptions, and behavioral consequences (Wang, 2008).

Perceived dependence can be measured in terms of the importance of the resources, the extent to which the party requires them, and the loss incurred if the relationship ended (Heide \& John, 1988; Kumar et al., 1995).

EO can be measured for both franchisor and franchisee, and EO of the partnership can be obtained as a multiplicative index. Or, EO items can be modified to measure EO of the relationship. Alternatively, EO can be measured for one party, with the perceived EO of the other party measured through separate questions, then multiplied.

Interdependence can be measured as the sum of both parties' dependence (Kumar et al., 1995) or as the product of the dependence of each party (Palmatier et al., 2007).

$\mathrm{Li}$ and Calantone's (1998) scale can be modified to the franchising context.

Following Vorhies and Morgan (2005), marketing capabilities can be assessed as marketing planning, implementation, information management, and marketing mix (4P) strategies.

Following Palmatier et al. (2007), RSI can be assessed as the time, effort and costs incurred specifically in the relationship.

Wood and Robertson's (2000) indicators for screening international markets can be reformulated for the franchising context.

John and Weitz (1988) provide a parsimonious five-item scale that measures volatility and turbulence. Dev and Brown (1995) review other scales.

Speed can be measured as the number of outlets divided by the time period. Scale of local market operations is the number of outlets in the country. Scope can be measured as geographic dispersion of outlets.

Following Srivastava et al. (1998), market-based assets include measures for brand equity and customer loyalty. Financial performance measures include sales, return on investments, or return on equity.

EO, Entrepreneurial Orientation; RSI, Relationship-Specific Investments.

Both act entrepreneurially in the creation of a new venture, namely the franchise outlet, and therefore the "extent and role of entrepreneurial activity within the franchise system" needs to be better understood (Falbe, Dandridge, \& Kumar, 1998, p. 127). We explore franchise partnerships through an entrepreneurship lens to derive implications for expansion in international markets. 
Franchising Theory and the Franchise Entrepreneurial Partnership

Franchising theory (exemplars)
Implications for franchise entrepreneurial partnership

\section{Resource constraints (Baker \& Dant, 2008; Caves \& Murphy, 1976; Oxenfeldt \& Kelly, 1968)}

Agency theory (Brickley \& Dark, 1987; Lafontaine, 1992; Rubin, 1978)

Transaction costs economics (Manolis, Dahlstrom, \& Nygaard, 1995; Windsperger, 2004)

Signaling theory (Dant \& Kaufmann, 2003; Gallini \& Lutz, 1992)

RBV (Barney, 1991; Barney, Wright, \& Ketchen, 2001)
Firms obtain scarce resources, including capital, for expansion and growth through franchising. However, ownership rather than franchising is preferred once these resources are available internally. Also, franchisors tend to own outlets that generate greater revenues and profits.

Firms prefer franchising for outlets, including those in distant locations that are particularly susceptible to managerial shirking and high monitoring costs. Franchise contracts should align the incentives of the franchisee with those of the franchisor.

Franchisors seek transaction-specific investments from franchisees to safeguard against opportunism and enhance franchisee bonding. Specific investments by the franchisor are needed for dependence balancing and incentive alignment.

To enlist franchisees, franchisors must demonstrate their own commitment and investments, have strong contracts, and undertake efforts to prop up the value of the franchise as a whole.

Firm resources are assets, capabilities, processes, routines, and knowledge. Habitual entrepreneurship encourages dynamic capabilities.
Entrepreneurial capital will be sought by franchisors seeking rapid growth and expansion in international markets. Franchisee's entrepreneurial role is largely restricted to risk-taking through capital investment and management.

Franchisors need to develop contractual incentives and control systems that are enforceable in multiple contexts. Franchise partnership and entrepreneurship is limited by contractual rights and responsibilities.

In distant markets, franchisors seek high initial investments from franchisees to mitigate the risks of opportunism. Franchisors must have clear policies and implementation procedures to reduce opportunism in the system. Mutual dependence strengthens the franchise partnership.

Franchisors should undertake actions that boost brand equity and profit potential to attract franchisees that may be committed to the relationship.

Habitual entrepreneurship creates new franchise resource configurations and helps leverage existing franchise resources in each subsequent franchise relationship.

RBV, Resource-based View.

\section{Role of Multi-Unit Master Franchising in International Expansion}

Most academic research treats the franchisee as an individual entrepreneur, whereas most franchisees in reality are multi-unit owners. Multi-unit ownership is more prevalent than individual-unit ownership, and it accounts for a vast majority of franchise systems (Grünhagen \& Mittelstaedt, 2005; Kaufmann \& Dant, 1996; Kaufmann \& Kim, 1995). Kaufmann (1996, p. 5) notes that "single-unit franchises are the exception, not the rule." The trend toward multi-unit ownership has become even more prevalent in the past two decades; research by the International Franchise Association suggests that more than 50\% of all franchises are owned by just $20 \%$ of franchisees. Some franchisors, such as Einstein Bros. Bagels, will work only with multi-unit franchisees (Daley, 2010). Thus, franchise expansion usually involves a new start-up by an existing franchisee, which leverages 
corporate efficiencies in resource deployment for start-up, training, management, and operations (Daley, 2010).

In international markets, franchisors often create partnerships with established firms in the host market, designated as a master franchisee, who are given the responsibility for developing the local market through multi-unit ownership or identifying and selling the rights to individual entrepreneurs within a specific geographic area (Alon, 2006; Gerhards, 2009; Ryans, Lotz, \& Krampf, 1999; Zwisler \& Wallman, 2010). Franchisors partner with master franchisees for multiple outlets because the high costs of adaptations in countries with vastly different environments may make it impossible for both the franchisor and the franchisee to recoup their investments from a single outlet (Zwisler \& Wallman). Single-unit franchising is relatively rare, such as when only one or two outlets are sufficient, as in the case of luxury hotels or resorts in small markets (Zwisler \& Wallman). Yet even these investment requirements might require partnership with a large, well-capitalized firm, rather than with a prospective individual entrepreneur.

Master franchisees obtain area development rights to set up a specific number of outlets over a defined period of time, either as their own outlets or subfranchised outlets (Gerhards, 2009; Zwisler \& Wallman, 2010). In either case, the arrangement is similar to a typical franchisor-franchisee relationship such that the franchisor collects initial fees and royalties from the master franchisee (Zwisler \& Wallman). Most international franchising therefore features two entities-franchisor and franchisees - that seek coordination through the franchise contract. In the emerging market of India, for example, the French retail chain Carrefour S.A. plans to open 150 hypermarkets through an alliance with a firm designated as its Indian master franchisee, Future Group (Sharma, 2010). Domino's Pizza also plans to open 65 outlets in conjunction with its master franchisee in India, Jubilant FoodWorks Ltd. (PR Newswire, 2010).

The master franchise arrangement allows for rapid market penetration in a geographical region or country, the acquisition of capital and other resources by the franchisor, the acquisition and spread of a proven business concept by the master franchisee firm, and the considerable resource sharing necessary for franchise expansion (Alon, 2006; Ryans et al., 1999; Zaid, 2010). Because the master franchisee is native to the specific region or country, it provides crucial support to the franchise partnership, in terms of knowledge of the local environment and laws, managerial skills for working with local personnel, cultural knowledge that might affect business practices, and political savvy in dealing with local governments, beyond the financial capital required for expansion (Ryans et al.). With these multiple requirements, "many franchisors prefer to do business with established companies" (Zwisler \& Wallman, 2010, p. 11). From the franchisors' perspective, multiunit ownership involves dealing with one partner in a specific geographical region and enables better coordination while also entrusting the franchise brand and operations to experienced and resource-rich franchisees (Daley, 2010). In contrast with the management problems inherent in monitoring and managing diverse international franchisees, the franchisor deals only with a limited number of master franchisees (Ryans et al.), which are often large and established entities in their local markets.

Exploratory research on the international expansion of retail franchisors by Doherty (2009) suggests that franchisors expand internationally through strategic franchise partner selection, such that they carefully and systematically seek out franchisee partners, or through opportunistic franchise partner selection, in which case they respond to prospective franchisees' inquiries and approaches. The franchisor's international expansion efforts can fail if it does not select the right partner as a master franchisee-if the "right chemistry" does not exist between the two partners (Doherty). Issues of conflict often involve ex-post contractual terms related to initial fees, royalties, taxes, regional 
development obligations, or exclusivity in territory (Zaid, 2010). The franchise partnership also could suffer from control and communication issues if the master franchisee does not follow the franchisor's directives or engage sufficiently in local area development (Ryans et al., 1999). Therefore, it is necessary to ensure that the master franchisee firm possesses the resources and motivations to engage in joint actions that mutually benefit the franchise partnership (Heide \& John, 1990).

Prior research has shown that multi-unit ownership by franchisees is motivated more by entrepreneurial motivations than purely investment motivations (Grünhagen \& Mittelstaedt, 2005). Entrepreneurship is generally understood as a firm-level process essential for new entry or the act of entering new or established markets with existing or new products and services (Lumpkin \& Dess, 1996). The key to entrepreneurship is the recognition of a market (or profit) opportunity and its exploitation through the assembly of necessary assets (Livesay, 1982). Because multi-unit franchise ownership or area development essentially involves sequential new entries, entrepreneurial actions are necessary for franchise expansion. The recognition and exploitation of new entry opportunities requires concerted joint actions. Therefore, the EOs of both the franchisor and the franchisee firms are essential to ensure entrepreneurial dynamics within the franchise partnership and, eventually, a successful franchise relationship.

Moreover, both firms depend on each other for the realization of specific objectives such that the perceived dependence of each party, which entails "the need to maintain a relationship to achieve goals" (Palmatier, Dant, \& Grewal, 2007, p. 175), can ensure the joint actions that lead to superior results (Heide \& John, 1990). The franchisor depends on the franchisee to achieve revenue maximization in a specific geographic region; the franchisee depends on the franchisor to maintain or enhance the franchise brand's reputation and receives business and operational support. The perceived dependence of each party, when balanced, leads to mutual dependence or interdependence (Heide \& John, 1988). Research in marketing has studied the impacts of both interdependence and dependence asymmetry and has concluded that interdependence has positive effects on relationships, whereas dependence asymmetry exerts negative impacts on performance (Gundlach \& Cadotte, 1994; Palmatier et al.). By recognizing that their interests are convergent, interdependent franchise partners develop commitment and trust, which reduces the problems and conflicts in their relationship (Kumar, Scheer, \& Steenkamp, 1995). Moreover, interdependence increases the level of adaptation undertaken by franchise partners (Hallen, Johanson, \& Seyed-Mohamed, 1991; Hibbard, Kumar, \& Stern, 2001), which is critical for new market entry, especially in international markets. In the following sections, we develop propositions regarding how the EO and interdependence of a franchise partnership might affect franchise expansions into new, especially international markets.

\section{EO of the Franchise Partnership}

Following Covin and Slevin (1989, 1991), Miller and Friesen (1982), and Miller (1983), Lumpkin and Dess (1996) identified the concept of EO as the single most important driver of firm-level entrepreneurship. EO is defined as "the processes, practices, and decision-making activities that lead to new entry" (Lumpkin \& Dess, p. 136; see Table 1). As elaborated by Rauch, Wiklund, Lumpkin, and Frese (2009, p. 762), EO also involves "strategy-making processes that provide organizations with a basis for entrepreneurial decisions and actions."

In their comprehensive meta-analysis of two decades of research, Rauch et al. (2009) note that a vast majority of prior research had studied EO in terms of its three 
dimensions-proactiveness, risk-taking, and innovativeness. Proactiveness refers to opportunity seeking; risk-taking involves committing resources in uncertain environments; and innovativeness is the "predisposition to engage in creativity and experimentation" (Rauch et al., p. 763). Thus, firms that exhibit an EO are more proactive, risk-taking, and innovative and better able to perceive and act on opportunities for new entry.

However, success in franchising requires that both the franchisor and the franchisee firms possess EO. Existing research on franchising has treated franchisor and franchisee entrepreneurship distinctly. For example, one research stream focuses on the entrepreneurial actions of the franchisor in establishing the franchise and developing brand and monitoring capabilities that can withstand competitive onslaughts, as well as on the franchisor's choice of franchising as an organizational form (Combs \& Ketchen, 2003; Fladmoe-Lindquist, 1996; Shane, 1996, 1998). Another stream of research acknowledges the franchisee entrepreneurship, with a focus on franchising as merely an entrepreneurial alternative (Kaufmann, 1999; Peterson \& Dant, 1990; Williams, 1998) or on the organizational factors that affect the franchisee's EO (Falbe et al., 1998). A perspective that considers the franchise relationship essentially an entrepreneurship partnership, as briefly recognized by Kaufmann and Dant (1998) and Shane and Hoy (1996), is underexplored in terms of its effects on franchise expansion and performance.

An EO influences not only the franchisor's choice of the franchise organization for expansion but also the selection of specific markets to enter. Franchisors with high EO should be innovative in their approach to franchising, select the optimal mix of contractual clauses (e.g., offering exclusivity to franchisees), and engage in business format innovations that are most likely to attract potential franchisees (Azoulay \& Shane, 2001). Despite risky decisions, franchisors with high EO would be more interested in partnering with entrepreneurial franchisee firms in host countries and in seeking out firms with a proven track record of business development rather than firms interested in the franchise purely for investment purposes (Grünhagen \& Mittelstaedt, 2005; Zwisler \& Wallman, 2010). Moreover, the decision about how and where to franchise requires high proactivity by the franchisor.

Similarly, entrepreneurial firms with high EO would prefer franchises that can bring their innovative abilities and other capabilities to fruition. Such franchisees may even prefer risky but high-growth franchise ventures to those that allow low but stable growth. They also would be proactive in reacting to local market demands and requesting adaptations that allow them to cater to such demand (Kaufmann \& Eroglu, 1998). For example, fast-food franchises may alter their products and services to cater to local market tastes (Kaufmann \& Eroglu). Franchisees with high EO are more likely to engage in such adaptations and maximize local demand to benefit the system as a whole, whereas those with low EO simply conform to national franchise standards and satisfy only suboptimal demand (Kaufmann \& Eroglu). The franchisor's EO thus drives innovations in the business format and the selection of franchisees and markets for new entry, whereas the franchisee's EO is important for responding to local market conditions and area development.

In addition to considering the $\mathrm{EO}$ of each partner, we argue for the need to consider the EO of the relationship. The EO of the franchise relationship can be defined as the extent to which the partners (i.e., franchisor and the franchisee) jointly engage in developing strategies and implementing entrepreneurial decisions and actions (see Table 1). Accordingly, it is important that both the franchisor and the franchisee firms have high-EO mindsets and engage in the innovative, risk-taking, and proactive strategies characteristic of that orientation. Existing research on EO further highlights the importance of such 
orientations for new entry; similarly, relatively high levels of EO in the franchise partnership may be needed to ensure continuous adaptations to local market conditions and the protection of competitive advantages. Thus, the EO of the relationship is more than simply a match or fit between the EO of the two partners; rather, each partner's EO is a precursor to developing relationship EO.

In turn, the concept of EO is central to understanding entrepreneurship and its impacts on business performance (Lumpkin \& Dess, 1996; Rauch et al., 2009). Strategic management literature reveals that an entrepreneurial culture positively influences a firm's intentions to expand and pursue new market opportunities (Autio, Sapienza, \& Almeida, 2000). Entrepreneurial risk-taking drives the strategic direction and allocation of resources, and proactiveness shapes strategic direction by encouraging the exploitation of emerging opportunities, as well as the creation of first-mover advantages (Dess, Lumpkin, \& Covin, 1997). Thus, entrepreneurial behavior facilitates early entrance into new markets for the franchisor and local market competitive advantages for the franchisee.

In the domain of international franchising, research shows that franchisors that expand internationally are quite different from those that remain concentrated in domestic environments (Huszagh, Huszagh, \& McIntyre, 1992). The expansion of a franchise system suggests that franchisee entrepreneurs must become entrepreneurial partners rather than relying on managers to build the necessary scale and scope of operations. Product and technological innovations enable the franchise to adapt to different geographic environments (Falbe et al., 1998). In a competitive environment, the EO of franchisees encourages the creation and enhancement of competitive advantages for the franchise as a whole (Baucus, Baucus, \& Human, 1996). Therefore, the successful expansion of franchises results from their innovative, risk-taking business models and customer interactions, often in cooperation with their franchisees.

The immediate impact of relationship EO is on franchise expansion particularly the speed, scale, and scope of activities undertaken in the franchise system. Summarizing prior research on franchise success and failures, Shane and Spell (1998) argue that the faster a franchisor creates multiple outlets, "the greater the chance that ... [the] chain would reach a scale to promote its brand name competitively before competitors could copy its outlet operations" (p. 46). Therefore, the speed of franchise expansion is critical for success, at least in the initial years of franchise formation, when the probability of failure is disproportionately high (Shane \& Spell).

Entrepreneurship speeds up franchise expansion because of the entrepreneurial partners' abilities to capitalize on opportunities before competitors can. Franchises with high EO can accumulate more resources and can quickly learn about new markets (Zahra, Ireland, \& Hitt, 2000), identify and respond to environmental cues faster than competitors (Wiklund \& Shepherd, 2003), and leverage market knowledge resources into market entry capabilities that maximize speed and efficiency. In research on international expansion by firms, Knight (2000) observes rapid expansion by entrepreneurial firms and notes a greater speed and scope of internationalization. Also, evidence of the effect of entrepreneurial firm characteristics on the choice and speed of firm internationalization has been documented in both developed and developing regions (McAuley, 1999; Zucchella, Palamara, \& Denicolai, 2007). Therefore, we propose:

Proposition 1: Greater EO of the franchise partnership enhances the franchise's speed of expansion.

The establishment of multiple outlets early, as is common in partnerships between a franchisor and a master franchisee, provides economies of scale in operational and marketing activities for the franchise. Shane, Shankar, and Aravindakshan (2006) argue 
that the need to expand the franchise system size, or build the scale of operations, is central to franchising as a business strategy. For example, as Shane and Spell (1998) observe, economies of scale in advertising would enable the promotion of brand names at lower costs per outlet. With the addition of each franchised outlet, the franchise system as a whole benefits because a bulk of the intangible expenditures of the fast-maturing franchise gets devoted to system-wide activities for all franchisees, such as brand management, advertising, operations and logistics, and other forms of support. Moreover, the replication of operational routines to each additional outlet requires only lower costs with each successive outlet (Shane \& Spell).

Because franchises often venture into uncharted territory, the need to minimize the risks and costs of new ventures often means they operate, at least in the beginning, below an efficient scale (Shane et al., 2006). Therefore, franchise growth, as indicated by system size, is important for not only survival but also the mitigation of uncertainties associated with new venture opportunities (Shane et al.). The EO of the franchise partners enables the realization of sufficient scale economies early so the franchise can engage fruitfully in the exploitation of new market opportunities. Moreover, as the system grows, the average cost of exploiting an opportunity falls, rendering the system more profitable (Shane et al.). Therefore, scale of operations is an important aspect of franchise expansion that affects success, and we submit:

Proposition 2: Greater EO of the franchise partnership enhances the franchise's scale of expansion.

Franchise expansion in the context of environmental and market diversity, which are characteristic of international markets, also may demand greater attention to the scope of activities and operations in multiple markets. First, franchise expansion is usually associated with greater geographic breadth (Carney \& Gedajlovic, 1991). Greater geographic coverage early may reflect not only the need to spread capital and monitoring costs but also a preemptive competitive strategy (Carney \& Gedajlovic). In most retail and service franchises, each outlet covers only a limited trading area; therefore, geographic expansion requires entrepreneurial identification and exploitation of additional new market entry opportunities (Julian \& Castrogiovanni, 1995). Second, because expansion into multiple markets may require local adaptations, the scope of operations of the franchise as a whole may expand with the geographic expansion of the franchise. In addition to adaptations to product and service offerings, there could be changes to the business format, such that the format of a mature franchise results from evolution rather than a one-time innovation (Kaufmann \& Eroglu, 1998). Franchise partnerships with high EO should be more likely to accept the risks associated with extensive adaptations. Franchise expansion is associated with increasing scope of the franchise system, and we propose:

Proposition 3: Greater EO of the franchise partnership enhances the franchise's scope of expansion.

\section{Interdependence and Franchise Expansion}

Franchising research acknowledges the mutual dependence of the franchisor and franchisee or interdependence in the franchise relationship. In elaborating on the structure of the franchise contract, Rubin (1978) argues that the franchisee is a distinct firm only legally, not economically. It is difficult to distinguish the boundaries of the two firms, or where the role of the franchisor ends and that of the franchisee begins. Further justification 
for interdependence comes from Dant and Gundlach (1998), who argue that dependence should be bilateral. The franchisor and the franchisee are mutually dependent for the performance of economic objectives and legal obligations. Such dependence is not a curb on autonomous actions by each party; rather, mutual dependence furthers the joint actions needed for performance and growth.

The franchise partnership thus benefits from interdependence (Dant \& Gundlach, 1998; Stanworth \& Curran, 1999), which involves balanced, high levels of dependence of each party that promote joint actions within the franchise partnership (Heide \& John, 1988). Recognition of interdependence in the franchise partnership by both parties enables them to realize that dependence is not a constraint on autonomy but simply a way to achieve superordinate or relationship-level objectives. Ultimately, the success of the franchise system creates a win-win situation for both the franchisor and the franchisee, so interdependence represents a way to realize convergent objectives.

Interdependence also enhances the relational bonds between the franchisor and the franchisee and enables better communication in terms of the amount, frequency, and quality of information shared in the franchise partnership (Mohr, Fisher, \& Nevin, 1996). Communication supports understanding of and achievement of systemic objectives, faster resolution of relationship and operational problems, and the creation of trust. Although interdependence may not directly affect performance, it does so through other proximate drivers (Palmatier et al., 2007). In the context of a franchising partnership, interdependence likely affects franchise expansion in the same manner as EO because a focus on convergent objectives and joint actions, along with better communications and trust, enables the franchise to achieve the speed, scale, and scope of operations necessary for franchise expansion. Therefore, we posit that:

Proposition 4: Greater perceived interdependence in the franchise partnership enhances the franchise's expansion in terms of (1) speed, (2) scale, and (3) scope of operations.

\section{Suggestions for Operationalization}

We have argued that a focus on the franchise partnership, rather than any one side of dyadic relationship between the franchisor and franchisee, helps clarify franchise expansion. Such a focus is relatively sparse in extant franchising research but more common in the study of marketing channels. The channel relationship, or the relationship between the firm and its supplier or distributor, is conceptualized as a partnership rather than a vertical power relationship (Anderson \& Narus, 1990). Similarly, even though a franchise contract undergirds the relationship between the franchisor and the franchisee, their working relationship is collaborative and geared toward the mutually beneficial success of the franchise. A partnership perspective therefore provides a better understanding of the joint actions they undertake to develop new markets and achieve strong performance for the franchise as a whole. The EO of the franchise partnership enables identification and exploitation of new market opportunities, and interdependence enables mutual and cooperative interest in expanding the "value pie" that the partners eventually share (Anderson \& Narus; Jap, 1999).

In terms of measuring EO, the meta-analysis by Rauch et al. (2009) suggests that prior research has usually obtained an EO score by summing the dimensions of innovativeness, risk-taking, and proactiveness. Moreover, the validity of Covin and Slevin's (1989) scale for EO persists when it is carefully modified (Rauch et al.). Therefore, in structural equation modeling, EO could be a second-order latent construct formed from its 
dimensions. For example, Wang (2008) used a modified 11-item scale to measure EO dimensions and extracted $\mathrm{EO}$ as a higher-order construct in a confirmatory factor analysis model that resulted in a good fit.

Marketing channels literature also provides some precedent for operationalizing the franchise partnership. In particular, in studies of dyadic relations, convergent and discriminant validity of measures is indicated at the level of the dyad as well as their being considerable perceptual agreement between each side of the dyad (Anderson \& Weitz, 1992; John \& Reve, 1982; Reve \& Stern, 1986). Similar methods could be used to operationalize EO and the interdependence of the franchise partnership.

For example, measures might ask both the franchisor and the franchisee to focus on their relationship and respond to EO items modified to reflect the relationship as opposed to the EO of each partner. Similarly, measures of the interdependence of franchise partners should be collected from both sides of the relationship. Thus, direct measures of EO and interdependence can be incorporated. Alternatively, indirect measures might be created through multiplicative indices or the use of polynomial regression (for a discussion of the pros and cons of such methods, see Edwards, 1994; Edwards \& Parry, 1993; Kristof, 1996).

In channels research, firm interdependence is operationalized as the product of the dependence of firm A on firm B and the dependence of firm B on firm A (Jap \& Ganesan, 2000; Palmatier et al., 2007). In a similar fashion, we suggest that researchers can operationalize the $\mathrm{EO}$ of the relationship as the product of the $\mathrm{EO}$ of the franchisor and the $\mathrm{EO}$ of the franchisee. Interdependence in the relationship can also be operationalized as the product of the perceived dependence of the franchisor on the franchisee and the perceived dependence of the franchisee on the franchisor. Data can be obtained from specific key informants from the franchisor and franchisee firms.

However, to measure firm-specific properties, either side of the dyad likely can provide adequate information as long as there is no key informant bias (i.e., the position of the person surveyed cannot influence his or her perspective) and the impact of measure specificity (i.e., variance due to stable measurement properties, such as wording) is reduced through careful selection of the key informants and questionnaire construction (Anderson, Zerrillo, \& Wang, 2006). Because EO and dependence are both firm-level constructs and can be measured as firm-level properties, either side of the partnership can support data collection. For example, if the franchisor is the informant, its dependence on the franchisee can be measured first, and then the franchisor's perceptions of the franchisee's dependence on it can be gathered from the same source, with subsequent analysis and controls for common methods bias (Anderson et al.).

Alternatively, the EO of the franchise partnership and interdependence of the franchise partners could be treated as distinct concepts and could be subjected to extensive measurement development and validation from both sides of the partnership. Measures that exhibit perceptual agreement (especially when the franchise relationship is strong) could be used to collect data from one side of the dyad, again with subsequent analysis and control for common method bias (Doty \& Glick, 1998).

\section{Moderating Effects of Franchise Resources}

To develop a comprehensive framework of the effects of franchise partnership on franchise expansion and performance, we also include some moderators identified in prior literature. We elaborate as well on the impacts on franchise performance.

Research into success factors for franchising has, among other factors, uncovered the importance of critical resources in the franchise system (Dant et al., 2007; Michael \& Combs, 2008; Shane, 1998; Shane \& Spell, 1998). One critical resource for franchise 
expansion is the brand name, because franchises that build brand recognition faster and adopt superior monitoring and administrative policies to protect their brand can expand faster and realize the benefits of scale and scope that accompanies such expansion (Fladmoe-Lindquist, 1996; Shane \& Spell). Managerial expertise and capital are also necessary for franchise expansion (Combs, Ketchen, \& Hoover, 2004; Dant et al.; Doherty, 2009). While a strong brand, managerial expertise, and capital may be available within the partnership, the impact of the franchise partnership on franchise expansion also requires other critical resources, such as local market knowledge, marketing capability, and relationship-specific assets.

Local Market Knowledge and Franchise Expansion. Local market knowledge comprises knowledge of customers and competitors in the local market. Research on the internationalization process suggests that the accumulation of knowledge from international operations results in a greater commitment to geographical expansion, because market knowledge resources reduce the uncertainty associated with such expansion efforts, and "knowledge moderates the speed at which perceived opportunity is exploited" (Oviatt \& McDougall, 2005, p. 546). Entrepreneurial strategic choices influence the firm's knowledge base (Shane, 2000) and market learning capabilities (Weerawardena, 2003), increase knowledge accumulation and conversion, and enable the franchise system to respond better to the market (Griffith, Noble, \& Chen, 2006).

Franchise systems that exhibit a high EO accumulate greater market knowledge resources, which enable them to gain useful new information about customers and competitors (Brockman \& Morgan, 2003) and the ability to recognize and exploit business opportunities and respond innovatively (Shane, 2000). Customer knowledge embodies all knowledge that the firm possesses about customers' current and potential needs, which enables the firm to create superior value (Gatignon \& Xuereb, 1997) by satisfying latent customer needs with innovative products or services (Day, 1994a; Sinkula, 1994). Competitor knowledge instead entails learning about competitors' products and strategies (Li \& Calantone, 1998) and is an integral part of firm strategy. Knowledge of customers and competitors also improves the franchise's speed and expertise in responding to customers. A customer orientation provides insights into customer preferences (Marinova, 2004), and a competitor orientation helps the firm identify and respond to competitors' actions (Day, 1994b; Gatignon \& Xuereb; Narver \& Slater, 1990). Combining market knowledge with operational routines as a means to customize products, implement exchanges, and enhance information should positively influence franchise expansion. Accelerated access to new markets can be achieved by such knowledge, and the entrepreneurial focus of the partnership enables it to leverage its cumulative knowledge (Baucus et al., 1996). Therefore, we offer:

Proposition 5a: Greater local market knowledge enhances the impact of the franchise partnership on franchise expansion.

Marketing Capability and Franchise Expansion. To derive value from customer and competitor knowledge and learning, any knowledge possessed must be effectively disseminated and deployed. The franchisor's marketing capability plays an important role by ensuring that market knowledge is internalized to enable innovations within the system (Li \& Cavusgil, 2000). Marketing capabilities are well-coordinated functional marketing activities achieved through skill, collective learning, and organizational processes (Day, 1994b). Some such capabilities relevant to international franchising include process innovations that improve the business format or the competitive advantages derived 
thereof, as well as product innovations that enable adaptations of the core products and services to different market environments.

Entrepreneurial franchises exhibit dynamic capabilities that reconfigure and leverage internal firm resources to create new competencies that provide first-mover advantages (Michael, 2003). Thus, the entrepreneurial culture of the franchise partnership promotes first-mover advantages by capitalizing more quickly on new opportunities unrecognized by competitors and enabling franchise expansion. Superior marketing capabilities, as evident in better marketing planning, information use, and the development of competitive marketing mix strategies, enables the partnership to preempt competition in local market expansion (Vorhies \& Morgan, 2005). Therefore, we posit:

Proposition 5b: Greater marketing capability enhances the impact of the franchise partnership on franchise expansion.

Relationship-Specific Investments (RSIs) and Franchise Expansion. It follows from the resource-based view (Barney, 1991) that partner firms need to invest in specific RSIs to build capabilities that create competitive advantages (Dyer \& Singh, 1998). These RSIs are heterogeneous, firm-specific idiosyncratic resources that, when combined, make the exchange valuable, rare, and difficult to duplicate. Such resources create sustainable competitive advantages and enable superior outcomes. Dyer and Singh posit that supernormal profits are realized in an exchange relationship when "partners combine, exchange, or invest in idiosyncratic assets, knowledge, and resources/capabilities" (p. 662). Such interfirm relationships, rich in RSIs, are a source of competitive advantage (Palmatier et al., 2007; Rindfleisch \& Moorman, 2001); the strength of the franchise partnership itself thus could support the joint actions that preempt the competition.

Although a firm's resources may be valuable, rare, and inimitable, it is the partnership's configuration of complementary internal and external resources that creates a competitive advantage (Barney, 1991). For example, the partnership's ability to apply internal resources and sustain superior value in turbulent environments represents a dynamic capability. When the deliverable is a service, the tacit knowledge and customization required, the complexity of the service, and the specificity of the customized relationship create ambiguity and decrease the likelihood of duplication (Bharadwaj, Varadarajan, \& Fahy, 1993). In this manner, combining unique firm resources and distinctive service skills within the partnership provides a competitive advantage that enables the partnership to exploit its served markets profitably (Javalgi, Griffith, \& White, 2003). Therefore, we submit that:

Proposition 5c: Greater investments in RSIs in the partnership enhance the impact of the franchise partnership on franchise expansion.

\section{Moderating Effects of Business/Market Conditions}

Franchising must contend with a myriad of environmental factors that affect the appropriateness of the franchise in the specific environment. First, although the franchise contract may be well developed, local laws and regulations, often intended to protect novice franchisees, may hinder its complete implementation. Second, specific franchise laws and regulations may have diverse and complex restrictions pertaining to disclosures, registrations, and relationships, particularly for international expansion (DLA Piper LLP, 2008). Third, even if the legal environment for franchising is favorable, other general business regulations could affect the local operations of the franchise system. Therefore, 
the standardization and adaptations required for franchise expansion could depend on factors beyond the control of the franchise partners.

For franchisors to recognize new market opportunities, business market conditions must be favorable in terms of market potential and growth prospects, and the environment needs to be conducive to a partnering relationship (Stewart, Watson, Carland, \& Carland, 1999). For example, in many emerging markets, opportunities abound as consumer purchasing power and the middle-class consumer segment continue to grow, which favor the expansion of food and other service businesses for which franchising is a common organizational arrangement (Schlentrich \& Aliouche, 2006; Sumrall, 2003). The presence of supportive environments, including legal and regulatory environments, market opportunities, and business market conditions, should induce varying effects of an EO on franchise internationalization (Wood \& Robertson, 2000). Therefore:

Proposition 6: The relationship between franchise partnership and franchise expansion is stronger when business/market conditions are favorable.

\section{Moderating Effects of Environmental Uncertainty}

Industry and sector environments differ in their degree of turbulence and dynamism, and some require highly flexible and innovative structures and business models (Eisenhardt \& Martin, 2000). A franchise expansion strategy requires coordinated activities across new, uncertain environments, and environmental turbulence likely affects firm growth. Strategic orientation has a stronger effect on performance when the firm's attributes align with the characteristics of the environment (Ketchen, Thomas, \& Snow, 1993). That is, entrepreneurial firms adapt to dynamic environments and exhibit better performance because they engage in proactive behaviors (Rauch et al., 2009).

Similarly, the franchise partnership's ability to capitalize on turbulence and gain a performance advantage requires an examination of and responsiveness to external forces over time. The franchise partnership, when focused on relational exchanges, can withstand environmental challenges. Empirical evidence suggests that relational exchanges outperform transaction-based exchanges when environmental uncertainty is high, because of their flexibility and ability to adapt to new conditions (Palmatier et al., 2007). Successful franchise relationships adapt to market diversity in new and dynamically changing markets. As uncertainty increases, relationship commitment and trust between the franchise partners promotes shared goals (Palmatier et al.). The franchise's competencies in managing its resources to create unique value continually and to thrive in dynamic, turbulent environments thus are critical to its sustainability and successful global expansion (Michael, 2003; Shane, 1996). In turn, entrepreneurial approaches to unique value creation should counter the effects of environmental turbulence and promote franchise expansion. We propose:

Proposition 7: The relationship between the franchise partnership and franchise expansion is stronger when environmental uncertainty is high.

\section{Influence of Franchise Expansion on Performance}

Franchise firms gain scale and scope benefits by exploiting market imperfections and by maximizing their use of locally generated resources and capabilities across multiple markets (Hitt, Hoskisson, \& Kim, 1997). In our franchising framework, we propose that geographic expansion positively affects performance through economies of scale (Capon, 
Farley, \& Hoenig, 1990), scope (Bercovitz \& Mitchell, 2007), and speed (Autio et al., 2000; Zahra et al., 2000). Specifically, scale and scope positively affect sales growth and return on equity in turbulent environments and enhance firm survival prospects by creating multiple market synergies.

Franchise performance comprises strategic performance (e.g., brand equity, customer equity) and financial performance (e.g., sales, profitability, return on investment, shareholder value). Strategic performance relates to the development of market-based assets that can be harnessed over a longer term to achieve superior financial performance (Srivastava, Shervani, \& Fahey, 1998). Successful franchises leverage a trusted brand and expand their business model to attain a greater scale and scope of operations for increased revenues. Once the brand is established in the local market, customers use these trusted brands as substitutes for product knowledge, turning a brand into a "touch point" that the firm can use to connect with customers, create value, and enhance loyalty (Bharadwaj et al., 1993). Leveraging this loyal customer base, the franchise can further expand its brand equity and customer lifetime equity. With increasing market scope, firms also can exploit their intangible assets (e.g., brand image, unique firm competencies, human or physical assets) across multiple markets.

Such is also the case when the franchise expands using master franchisees. Research, which examines intra-market diversification, indicates that greater regional diversification positively enhances performance (Qian, Khoury, Peng, \& Qian, 2010). In the context of intra-region franchise expansion or master franchisee agreements, a franchisor reduces investment risk and monitoring costs by leveraging the master franchisee's local market knowledge. Thus, franchisors that expand internationally and intra-regionally would experience lower adaptation, monitoring, and management costs in dealing with a limited number of master franchisees, which recoups investment costs more quickly for accelerated and profitable expansion.

Expansion yields positive performance benefits because it allows firms to leverage their internal resources across more markets. Hitt et al. (1997) assert that geographic expansion increases a firm's flexibility and bargaining power, with consequent higher economies of scale and the amortization of the firm's resource investments over a broader span of markets. Greater inter-regional diversification offers performance advantages as capabilities are leveraged to a point before excessive investments and coordination costs erode profits (Qian et al., 2010). Entrepreneurial franchises possess dynamic capabilities, which they reconfigure to create additional resources (Covin \& Slevin, 1991; Eisenhardt \& Martin, 2000) or influence market changes that promote new forms of competitive advantage. A focus on the customer and the cocreation of value pushes a firm's strategy to evolve with customers' preferences, even in a dynamic global marketplace (Prahalad \& Ramaswamy, 2004). Therefore, we propose:

Proposition 8: Speed, scale, and scope of franchise expansion have positive effects on strategic and financial performance.

\section{Moderating Effects on Franchise Expansion and Franchise Performance}

Competitive intensity and other environmental factors moderate the effects of franchise expansion on performance (Lu \& Beamish, 2001; Zhou, Yim, \& Tse, 2005). The sustained advantages of several U.S.-based fast-food restaurants and hotels in international markets exemplify their ability to thrive in environments marked by frequent changes in demand preferences, an accelerated pace of technological change, and intense competition. Their successes result from risky new strategies and innovative business 
models that extend their reach and encourage customer loyalty through new forms of value and customer interactions. The ability to thrive in turbulent environments also depends on the firm's capability to align its resources and counter environmental turbulence so as to create differentiated value and persistent advantages. Thus, entrepreneurial intensity clearly offers a capability-building activity that creates superior performance and a sustainable competitive advantage (Weerawardena, 2003). In summary, joint actions in the franchise partnership help overcome environmental challenges and nurture distinctive skills for sustainable performance advantages, even in turbulent environments. We propose:

Proposition 9: The relationship between franchise expansion and franchise performance is stronger when environmental uncertainty is high.

\section{Conclusion}

In the preceding sections, we have investigated the franchise partnership by noting its entrepreneurial characteristics and developed a framework that argues that an entrepreneurial partnership is critical for franchise expansion and performance. Some prior academic research has conceived of the franchisor-franchisee relationship as an entrepreneurial partnership (e.g., Kaufmann \& Dant, 1998; Shane \& Hoy, 1996); we have elaborated on the entrepreneurial and interdependence characteristics of the franchise partnership and extended its effects to franchise expansion, particularly in international markets. Our conceptualization and the comprehensive model we develop to link the franchise partnership to franchise expansion and performance sheds additional light on the factors that are important for successful franchising in international markets. The model demands empirical validation, and we have offered some suggestions on the operationalization of the key constructs in Table 2. We also offer some possible implications and suggestions for further research.

\section{Implications for Franchise Strategy}

An entrepreneurial focus is critical to successful franchise expansion and to achieve superior positions; therefore, franchisors must seek out master franchisee firms with high EO. As Doherty (2009) reveals, there must be chemistry between the franchisor and the franchisee, and our model maintains that an alignment of EO and interdependence is essential to create a successful franchise partnership.

Furthermore, the entrepreneurial partnership must focus on developing trust and enhancing the value of the franchise through appropriate brand-building efforts. A perception of dependence between partners signals their significant stakes in the relationship and increases interest in maintaining the relationship (Ganesan, 1994; Lusch \& Brown, 1996). Interdependence enhances franchise performance, because the partners' dependence on each other increases their desire to maintain the relationship and the adaptations they undertake (Hibbard et al., 2001).

Because relationships demand the application of specialized knowledge and skills, superior value results when both exchange partners invest in RSIs, share knowledge, and invest in marketing capabilities (Dyer \& Singh, 1998; Palmatier et al., 2007). Unique investments in the relationship that are not easily recovered (Ganesan, 1994) signal a franchise partner's commitment and perception of the value of the partnership, which enhances partners' desire to maintain the relationship. Strong relationships increase sales 
and profits (Palmatier, Dant, Grewal, \& Evans, 2006), facilitate innovations, expand markets, and reduce costs (Rindfleisch \& Moorman, 2001). In dynamic, diverse environments, strong franchise relationships, built on mutual goals and trust, perform better in internationally diverse, highly uncertain, and competitive marketplaces.

In summary, franchise success stems from improving the effectiveness and efficacy of relationship value creation by managing resources across diverse contexts. A competitive advantage in franchising derives from the combined effect of entrepreneurial actions and firm-specific knowledge resources. There is evidence that global franchises create competitive advantages by leveraging managerial capabilities across global markets to recognize, develop, and exploit market information and technology resources that enhance their capabilities across business processes and create unique value.

\section{Further Research}

This article responds to persistent calls for research that goes beyond current dominant perspectives and supports a more integrated view of franchise expansion and performance while delving into the intricacies of the franchisor-franchise relationship (Dant, 2008). This article aims to spur academic research at the nexus of franchising, entrepreneurship, and strategy, especially pertaining to how sustainable competitive advantages in franchise expansion can be developed through the entrepreneurial and resource-sharing partnership of the franchisor and franchisee. Our proposed framework suggests that entrepreneurial approaches to knowledge use and value creation influence the speed, scale, and scope of franchise internationalization, as well as the development of a sustainable competitive advantage for long-term superior performance.

However, the framework requires empirical testing to confirm its contribution. The concepts we used to develop our theory have been well examined, with the exception of our introduction of the partnership EO concept. As we have noted, several approaches could be used to operationalize and measure this form of EO, some of which are based on prior research in marketing channels that measures the interdependence of channel partnerships. Further research should examine empirically the relationships we propose in our framework.

As franchise relationships become more complex due to the influence of intelligent technologies, unique emerging market conditions, and diverse legal and business environments, franchising research must explore not only the factors needed for superior competitive performance but also successful adaptations to dynamic and complex international environments. We hope that our model provides useful building blocks for multidisciplinary research on franchise partnerships, entrepreneurship, expansion, and performance.

\section{REFERENCES}

Alon, I. (2006). Market conditions favoring master international franchising. Multinational Business Review, $14(2), 67-82$.

Anderson, E. \& Weitz, B.A. (1992). The use of pledges to build and sustain commitment in distribution channels. Journal of Marketing Research, 29(1), 18-34.

Anderson, J.C. \& Narus, J.A. (1990). A model of distributor firm and manufacturer firm working partnerships. Journal of Marketing, 54(1), 42-58. 
Anderson, J.C., Zerrillo, P.C. Sr., \& Wang, L.O. (2006). Estimating firm-specific and relational properties in interorganizational relationships in marketing. Journal of Business-to-Business Marketing, 13(4), $29-67$.

Autio, E., Sapienza, H.J., \& Almeida, J.G. (2000). Effects of age at entry, knowledge intensity, and imitability on international growth. Academy of Management Journal, 43(5), 909-924.

Azoulay, P. \& Shane, S. (2001). Entrepreneurs, contracts and failure of young firms. Management Science, 47(3), 337-358.

Baker, B.L. \& Dant, R.P. (2008). Stable plural forms in franchise systems: An examination of the evolution of ownership redirection research. In G. Hendrikse, M. Tuunanen, J. Windsperger, \& G. Cliquet (Eds.), Strategy and governance of networks: Cooperatives, franchising, and strategic alliances (pp. 87-112). Heidelberg, Germany: Physica-Verlag (Springer).

Barney, J. (1991). Firm resources and sustained competitive advantage. Journal of Management, 17(1), 99-120.

Barney, J., Wright, M., \& Ketchen, D.J., Jr. (2001). The resource-based view of the firm: Ten years after 1991. Journal of Management, 27(6), 625-642.

Baucus, D.A., Baucus, M.S., \& Human, S.E. (1996). Consensus in franchise organizations: A cooperative arrangement among entrepreneurs. Journal of Business Venturing, 11, 359-378.

Bercovitz, J. \& Mitchell, W. (2007). When is more better? The impact of business scale and scope on long-term business survival, while controlling for profitability. Strategic Management Journal, 28(1), 61-79.

Bharadwaj, S.G., Varadarajan, R.P., \& Fahy, J. (1993). Sustainable competitive advantage in service industries: A conceptual model and research propositions. Journal of Marketing, 57(4), 83-99.

Brickley, J.A. \& Dark, F.H. (1987). The choice of organizational form: The case of franchising. Journal of Financial Economics, 18, 401-420.

Brockman, B.K. \& Morgan, R.M. (2003). The role of existing knowledge in new product innovativeness and performance. Decision Sciences, 34(2), 385-419.

Capon, N., Farley, J.U., \& Hoenig, S. (1990). Determinants of financial performance: A meta-analysis. Management Science, 36(10), 1143-1159.

Carney, M. \& Gedajlovic, E. (1991). Vertical integration in franchise systems: Agency theory and resource explanations. Strategic Management Journal, 12, 607-629.

Caves, R.E. \& Murphy, W.F. (1976). Franchising: Firms, markets and intangible assets. Southern Economic Journal, 42(April), 572-586.

Combs, J.G. \& Castrogiovanni, G.J. (1994). Franchisor strategy: A proposed model and empirical test of franchise versus company ownership. Journal of Small Business Management, 32(2), 37-48.

Combs, J.G. \& Ketchen, D.J., Jr. (2003). Why do firms use franchising as an entrepreneurial strategy? A meta-analysis. Journal of Management, 29(3), 443-465.

Combs, J.G., Ketchen, D.J., Jr., \& Hoover, V.L. (2004). A strategic groups approach to the franchisingperformance relationship. Journal of Business Venturing, 19, 877-897.

Covin, J.G. \& Slevin, D.P. (1989). Strategic management of small firms in hostile and benign environments. Strategic Management Journal, 10(1), 75-87.

Covin, J.G. \& Slevin, D.P. (1991). A conceptual model of entrepreneurship as firm behavior. Entrepreneurship Theory and Practice, 16(1), 7-25. 
Daley, J. (2010, July). The big time: Multiple-unit ownership has taken over the franchise world. Entrepreneur Magazine. Available at http://www.entrepreneur.com/magazine/entrepreneur/2010/july/207192.html, accessed 8 July 2010.

Dant, R.P. (2008). A futuristic research agenda for the field of franchising. Journal of Small Business Management, 46(1), 91-98.

Dant, R.P. \& Gundlach, G.T. (1998). The challenge of autonomy and dependence in franchise channels of distributions. Journal of Business Venturing, 14(1), 35-68.

Dant, R.P., Kacker, M., Coughlan, A.T., \& Emerson, J. (2007). A cointegration analysis of the correlates of performance in franchised channels. In G. Cliquet, M. Tuunanen, G. Hendrikse, \& J. Windsperger (Eds.), Economics and management of networks: Franchising networks, cooperatives, joint ventures and alliances (pp. 169-189). Heidelberg, Germany: Physica-Verlag (Springer).

Dant, R.P. \& Kaufmann, P.J. (2003). Structural and strategic dynamics in franchising. Journal of Retailing, 79, $63-75$.

Day, G.S. (1994a). Continuous learning about markets. California Management Review, 36(4), 9-31.

Day, G.S. (1994b). The capabilities of market-driven organizations. Journal of Marketing, 58(4), 37-53.

Dess, G.G., Lumpkin, G.T., \& Covin, J.G. (1997). Entrepreneurial strategy making and firm performance: Tests of contingency and configurational models. Strategic Management Journal, 18(9), 677-695.

Dev, C.S. \& Brown, J.R. (1995). Measuring environmental uncertainty. International Review of Retail, Distribution and Consumer Research, 5(April), 219-247.

DLA Piper LLP. (2008, December). Executive summary of franchise laws around the world. Available at http://www.franchise.org/uploadedFiles/Files/Executive_Summary_Franchise_Laws_World.pdf, accessed 4 February 2009.

Doherty, A.M. (2009). Market and partner selection processes in international retail franchising. Journal of Business Research, 62, 528-534.

Doty, D.H. \& Glick, W.H. (1998). Common methods bias: Does common methods variance really bias results? Organizational Research Methods, 1(October), 374-406.

Dyer, J.H. \& Singh, H. (1998). The relational view: Cooperative strategy and sources of interorganizational competitive advantage. Academy of Management Review, 23(4), 660-679.

Edwards, J.R. (1994). The study of congruence in organizational behavior research: Critique and a proposed alternative. Organizational Behavior and Human Decision Processes, 58(1), 51-100.

Edwards, J.R. \& Parry, M.E. (1993). On the use of polynomial regression equations as an alternative to difference scores in organizational research. Academy of Management Journal, 36(6), 1577-1613.

Eisenhardt, K.M. \& Martin, J.A. (2000). Dynamic capabilities: What are they? Strategic Management Journal, 21(10/11), 1105-1122.

Falbe, C.M., Dandridge, T.C., \& Kumar, A. (1998). The effect of organizational context on entrepreneurial strategies in franchising. Journal of Business Venturing, 14, 125-140.

Fladmoe-Lindquist, K. (1996). International franchising: Capabilities and development. Journal of Business Venturing, 11, 419-438.

Gallini, N.T. \& Lutz, N.A. (1992). Dual distribution and royalty fees in franchising. Journal of Law, Economics \& Organization, 8(3), 471-501. 
Ganesan, S. (1994). Determinants of long-term orientation in buyer-seller relationships. Journal of Marketing, $58(2), 1-19$.

Gatignon, H. \& Xuereb, J.-M. (1997). Strategic orientation of the firm and new product performance. Journal of Marketing Research, 34(1), 77-90.

Gerhards, E.E.V. (2009). When is a development agent or similar third party a franchisor? Franchise Law Journal, 2(2), 106-112.

Griffith, D.A., Noble, S.M., \& Chen, Q. (2006). The performance implications of entrepreneurial proclivity: A dynamic capabilities approach. Journal of Retailing, 82(1), 51-62.

Grünhagen, M. \& Mittelstaedt, R.A. (2005). Entrepreneurs or investors: Do multi-unit franchisees have different philosophical orientations? Journal of Small Business Management, 43(3), 207-225.

Gundlach, G.T. \& Cadotte, E.R. (1994). Exchange interdependence and interfirm interaction: Research in a simulated channel setting. Journal of Marketing Research, 31(4), 516-532.

Hallen, L., Johanson, J., \& Seyed-Mohamed, N. (1991). Interfirm adaptation in business relationships. Journal of Marketing, 55(April), 29-37.

Heide, J.B. \& John, G. (1988). The role of dependence balancing in safeguarding transaction-specific assets in conventional channels. Journal of Marketing, 52(1), 20-35.

Heide, J.B. \& John, G. (1990). Alliances in industrial purchasing: The determinants of joint actions in buyer-supplier relationships. Journal of Marketing Research, 27(1), 24-36.

Hibbard, J.D., Kumar, N., \& Stern, L.W. (2001). Examining the impact of destructive acts in marketing channels relationship. Journal of Marketing Research, 38(1), 25-61.

Hitt, M.A., Hoskisson, R.E., \& Kim, H. (1997). International diversification: Effects on innovation and firm performance in product-diversified firms. Academy of Management Journal, 40(4), 767-799.

Huszagh, S.M., Huszagh, F.W., \& McIntyre, F.S. (1992). International franchising in the context of competitive strategy and the theory of the firm. International Marketing Review, 9(5), 5-18.

Jap, S.D. (1999). Pie-expansions efforts: Collaboration processes in buyer-supplier relationships. Journal of Marketing Research, 36(November), 461-475.

Jap, S.D. \& Ganesan, S. (2000). Control mechanisms and the relationship lifecycle: Implications for safeguarding specific investments and developing commitment. Journal of Marketing Research, 37(2), 227-245.

Javalgi, R.G., Griffith, D.A., \& White, D.S. (2003). An empirical examination of factors influencing the internationalization of service firms. Journal of Services Marketing, 17(2), 185-202.

John, G. \& Reve, T. (1982). The reliability and validity of key informant data from dyadic relationships in marketing channels. Journal of Marketing Research, 19(4), 517-524.

John, G. \& Weitz, B.A. (1988). Forward integration into distribution: Empirical test of transaction cost analysis. Journal of Law, Economics \& Organization, 4(Fall), 121-139.

Julian, S. \& Castrogiovanni, G.J. (1995). Franchisor geographic expansion. Journal of Small Business Management, 33(2), 1-11.

Kaufmann, P.J. (1996). The state of research in franchising. Franchising Research: An International Journal, $1(1), 4-7$.

Kaufmann, P.J. (1999). Franchising and the choice of self-employment. Journal of Business Venturing, 14(4), 345-362. 
Kaufmann, P.J. \& Dant, R.P. (1996). Multiunit franchising: Growth and management issues. Journal of Business Venturing, 11(5), 343-358.

Kaufmann, P.J. \& Dant, R.P. (1998). Franchising and the domain of entrepreneurship research. Journal of Business Venturing, 14, 5-16.

Kaufmann, P.J. \& Eroglu, S. (1998). Standardization and adaptation in business format franchising. Journal of Business Venturing, 14, 69-85.

Kaufmann, P.J. \& Kim, S.H. (1995). Master franchising and system growth rates. Journal of Marketing Channels, 4(1/2), 49-64.

Ketchen, D.J., Jr., Thomas, J.B., \& Snow, C.C. (1993). Organizational configurations and performance: A comparison of theoretical approaches. Academy of Management Journal, 36(6), 1278-1314.

Knight, G.A. (2000). Entrepreneurship and marketing strategy: The SME under globalization. Journal of International Marketing, 8(2), 12-32.

Kristof, A.L. (1996). Person-organization fit: An integrative review of its conceptualizations, measurement, and implications. Personnel Psychology, 49(1), 1-49.

Kumar, N., Scheer, L.K., \& Steenkamp, J.-B.E.M. (1995). The effects of perceived interdependence on dealer attitudes. Journal of Marketing Research, 32(3), 348-356.

Lafontaine, F. (1992). Agency theory and franchising: Some empirical results. RAND Journal of Economics, 23(Summer), 263-283.

Leblebici, H. \& Shalley, C.E. (1996). The organization of relational contracts: The allocation of rights in franchising. Journal of Business Venturing, 11(5), 403-418.

Li, T. \& Calantone, R.J. (1998). The impact of market knowledge competence on new product advantage: Conceptualization and reexamination. Journal of Marketing, 62(4), 13-29.

Li, T. \& Cavusgil, S.T. (2000). Decomposing the effects of market knowledge competence in new product export. European Journal of Marketing, 34(1/2), 57-80.

Livesay, H.C. (1982). Entrepreneurial history. In C.A. Kent, D.L. Sexton, \& K.H. Vesper (Eds.), Encyclopedia of entrepreneurship (pp. 7-15). Englewood Cliffs, NJ: Prentice-Hall.

Lu, J.W. \& Beamish, P.W. (2001). The internationalization and performance of SMEs. Strategic Management Journal, 22(6/7), 565-587.

Lumpkin, G.T. \& Dess, G.G. (1996). Clarifying the entrepreneurial orientation construct and linking it to performance. Academy of Management Review, 21(1), 135-172.

Lusch, R.F. \& Brown, J.R. (1996). Interdependency, contracting, and relational behavior in marketing channels. Journal of Marketing, 60(4), 19-38.

McAuley, A. (1999). Entrepreneurial instant exporters in the Scottish arts and crafts sector. Journal of International Marketing, 7(4), 67-82.

Manolis, C., Dahlstrom, R., \& Nygaard, A. (1995). A preliminary investigation of ownership conversions in franchised distribution systems. Journal of Applied Business Research, 11(2), 1-8.

Marinova, D. (2004). Actualizing innovation effort: The impact of market knowledge diffusion in a dynamic system of competition. Journal of Marketing, 68(3), 1-20.

Michael, S.C. (2002). Can a franchise chain coordinate? Journal of Business Venturing, 17, 325-341. 
Michael, S.C. (2003). First mover advantage through franchising. Journal of Business Venturing, 18, 61-80.

Michael, S.C. \& Combs, J.G. (2008). Entrepreneurial failure: The case of franchisees. Journal of Small Business Management, 46(1), 73-90.

Miller, D. (1983). The correlates of entrepreneurship in three types of firms. Management Science, 29(7), 770-791.

Miller, D. \& Friesen, P.H. (1982). Innovation in conservative and entrepreneurial firms: Two models of strategic momentum. Strategic Management Journal, 3, 1-25.

Mohr, J.J., Fisher, R.J., \& Nevin, J.R. (1996). Collaborative communication in interfirm relationships: Moderating effects of integration and control. Journal of Marketing, 60(3), 103-115.

Narver, J.C. \& Slater, S.F. (1990). The effect of a market orientation on business profitability. Journal of Marketing, 54(4), 20-35.

Oviatt, B.M. \& McDougall, P.P. (2005). Defining international entrepreneurship and modeling the speed of internationalization. Entrepreneurship Theory and Practice, 29(5), 537-553.

Oxenfeldt, A.R. \& Kelly, A.O. (1968). Will successful franchise systems ultimately become wholly-owned chains? Journal of Retailing, 44(Winter), 69-83.

Palmatier, R.W., Dant, R.P., \& Grewal, D. (2007). A longitudinal analysis of theoretical perspectives of interorganizational relationship performance. Journal of Marketing, 71(October), 172-194.

Palmatier, R.W., Dant, R.P., Grewal, D., \& Evans, K.R. (2006). Factors influencing the effectiveness of relationship marketing: A meta-analysis. Journal of Marketing, 70(4), 136-153.

Peterson, A. \& Dant, R.P. (1990). Perceived advantages of the franchise option from the franchisee perspective: Empirical insights from a service franchise. Journal of Small Business Management, 3, 4661.

PR Newswire. (2010). Domino's Pizza opens 9,000th store; company celebrates with symbolic openings in New Delhi \& New Orleans. March 11.

Prahalad, C.K. \& Ramaswamy, V. (2004). Co-creating unique value with customers. Strategy \& Leadership, 32(3), 4-9.

Qian, G., Khoury, T.A., Peng, M.W., \& Qian, Z. (2010). The performance implications of intra- and inter-regional geographic diversification. Strategic Management Journal, 31(9), 1018-1039.

Rauch, A., Wiklund, J., Lumpkin, G.T., \& Frese, M. (2009). Entrepreneurial orientation and business performance: An assessment of past research and suggestions for the future. Entrepreneurship Theory and Practice, 33(May), 761-787.

Reve, T. \& Stern, L.W. (1986). The relationship between interfirm form, transaction climate, and economic performance in vertical interfirm dyads. In L. Pellegrini \& S. Reddy (Eds.), Marketing channels (pp. 75-102). Lexington, MA: Lexington Books.

Rindfleisch, A. \& Moorman, C. (2001). The acquisition and utilization of information in new product alliances: A strength-of-ties perspective. Journal of Marketing, 65, 1-18.

Rubin, P.H. (1978). The theory of the firm and the structure of the franchise contract. Journal of Law and Economics, 21(April), 223-233.

Ryans, J.K., Jr., Lotz, S., \& Krampf, R. (1999). Do master franchisors drive global franchising? Marketing Management, 8(2), 32-37. 
Schlentrich, U. \& Aliouche, H. (2006). Rosenberg center study confirms global franchise growth. Franchising World, 38(August), 63-65.

Shane, S. (1996). Why franchise companies expand overseas. Journal of Business Venturing, 11, 73-88.

Shane, S. (1998). Making new franchise systems work. Strategic Management Journal, 19(July), 697-707.

Shane, S. (2000). Prior knowledge and the discovery of entrepreneurial opportunities. Organization Science, $11(4), 448-470$.

Shane, S. (2001). Organizational incentives and organizational mortality. Organization Science, 12(2), 136160 .

Shane, S. \& Hoy, F. (1996). Franchising: A gateway to cooperative entrepreneurship. Journal of Business Venturing, 11, 325-327.

Shane, S., Shankar, V., \& Aravindakshan, A. (2006). The effects of new franchisor partnering strategies on franchise system size. Management Science, 52(5), 773-787.

Shane, S. \& Spell, C. (1998). Factors for new franchise success. Sloan Management Review, 39(Spring), 43-50.

Sharma, S. (2010, May 5). France's Carrefour plans 150 hypermarkets. DNA: Daily News \& Analysis. Available at http://www.dnaindia.com/money/report_france-s-carrefour-plans-150-hypermarts_1379126, accessed 17 June 2010.

Sinkula, J.J. (1994). Market information processing and organizational learning. Journal of Marketing, 58(1), $35-45$.

Srivastava, R., Shervani, T., \& Fahey, L. (1998). Market-based assets and shareholder value: A framework for analysis. Journal of Marketing, 62, 2-18.

Stanworth, J. \& Curran, J. (1999). Colas, burgers, shakes, and shirkers: Towards a sociological model of franchising in the market economy. Journal of Business Venturing, 14(4), 323-344.

Stewart, W.H., Watson, W.E., Carland, J.C., \& Carland, J.W. (1999). A proclivity for entrepreneurship: A comparison of entrepreneurs, small business owners, and corporate managers. Journal of Business Venturing, 14(March), 189-214.

Sumrall, C.R. (2003). Are you ready to go global? Franchising World, 35(October), 27-28.

Vorhies, D.W. \& Morgan, N.A. (2005). Benchmarking marketing capabilities for sustainable competitive advantage. Journal of Marketing, 69(January), 80-94.

Wang, C.L. (2008). Entrepreneurial orientation, learning orientation, and firm performance. Entrepreneurship Theory and Practice, 32(4), 635-657.

Weerawardena, J. (2003). Exploring the role of market learning capability in competitive strategy. European Journal of Marketing, 37(3/4), 407-429.

Wiklund, J. \& Shepherd, D. (2003). Knowledge-based resources, entrepreneurial orientation, and the performance of small and medium-sized businesses. Strategic Management Journal, 24(13), 1307-1314.

Williams, D.L. (1998). Why do entrepreneurs become franchisors? An empirical analysis of organizational choice. Journal of Business Venturing, 14, 103-124.

Windsperger, J. (2004). The dual network structure of franchising firms: Property rights, resource scarcity and transaction cost explanations. In J. Windsperger, G. Hendrikse, G. Cliquet, \& M. Tuunanen (Eds.), Economics and management of franchising networks (pp. 69-88). Heidelberg, Germany: Physica-Verlag (Springer). 
Wood, V.R. \& Robertson, K.R. (2000). Evaluating international markets: The importance of information by industry, by country of destination, and by type of export transaction. International Marketing Review, 17(1), $34-56$.

Zahra, S.A., Ireland, R.D., \& Hitt, M.A. (2000). International expansion by new venture firms: International diversity, mode of market entry, technological learning, and performance. Academy of Management Journal, 43(5), 925-950.

Zaid, F. (2010). Keep your international expansion expectations realistic. Franchising World, 42(February), 63-66.

Zhou, K.Z., Yim, B., \& Tse, D.K. (2005). The effects of strategic orientations on technology and market-based breakthrough innovations. Journal of Marketing, 69(April), 42-60.

Zucchella, A., Palamara, G., \& Denicolai, S. (2007). The drivers of the early internationalization of the firm. Journal of World Business, 42(3), 268-280.

Zwisler, C.E. \& Wallman, K.L. (2010). Match your brand to the best international market. Franchising World, 42(March), 9-11.

Dhruv Grewal is the Toyota Chair of Commerce and Electronic Business and Professor of Marketing at Babson College.

Gopalkrishnan R. Iyer is Professor of Marketing and Director, Center for Services Marketing \& Management at the Florida Atlantic University.

Rajshekhar (Raj) G. Javalgi is the Associate Dean and Professor of Marketing and International Business in the Nance College of Business Administration at the Cleveland State University.

Lori Radulovich is Associate Professor of Business Administration at Baldwin-Wallace College. 